\title{
Circadian Rhythms in Urinary Functions: Possible Roles of Circadian Clocks?
}

\author{
Jong-Yun Noh ${ }^{1,2}$, Dong-Hee Han ${ }^{1,2}$, Ji-Ae Yoon ${ }^{1,2}$, Mi-Hee Kim ${ }^{1,2}$, Sung-Eun Kim³ ${ }^{3}$ Il-Gyu Ko ${ }^{3}$, Khae-Hawn Kim4, \\ Chang-Ju Kim ${ }^{3}$, Sehyung $\mathrm{Cho}^{1,2,3}$ \\ ${ }^{1}$ Graduate Program for Neuroscience, ${ }^{2}$ Neurodegeneration Control Research Center, ${ }^{3}$ Department of Physiology, \\ Kyung Hee University School of Medicine, Seoul; \\ ${ }^{4}$ Department of Urology, Gachon University Gil Hospital, Gachon University of Medicine and Science, Incheon, Korea
}

\begin{abstract}
Circadian clocks are the endogenous oscillators that harmonize a variety of physiological processes within the body. Although many urinary functions exhibit clear daily or circadian variation in diurnal humans and nocturnal rodents, the precise mechanisms of these variations are as yet unclear. In this review, we briefly introduce circadian clocks and their organization in mammals. We then summarize known daily or circadian variations in urinary function. Importantly, recent findings by others as well as results obtained by us suggest an active role of circadian clock genes in various urinary functions. Finally, we discuss possible research avenues for the circadian control of urinary function.
\end{abstract}

Keywords: Circadian clocks; Urinary bladder; Urination; Urinary function

\section{INTRODUCTION}

One of the most predictable environmental changes on this rotating planet is undoubtedly the alternations of day and night, which accompany daily variations in environmental illumination, ambient temperature, humidity, and food and predator availability. Organisms that can predict, and prepare themselves in advance for, these environmental changes have selective advantages over those who cannot accommodate themselves until the changes of environment have taken place. Indeed, almost every life form on Earth displays distinct daily or circadian variations in biochemistry, physiology, pathology, and behavior [1-4].

The advent of endogenous circadian clocks seems to be a recent innovation in the history of life, because the core molecules that derive oscillatory functions within the cell have multiple origins among different forms of life [1]. Gehring and Rosbash [5] once hypothesized that the origin of circadian clocks in ear- ly metazoans might be a coupling of blue light receptors to molecular oscillators to avoid excess oxidative stress induced by light [6]. In support of this notion, the phases of DNA replication, DNA repair, and the cell cycle are found appropriately positioned in a given day-night cycle to minimize the damage $[7,8]$. Moreover, disturbances to the circadian rhythm and knockouts of clock genes lead to various oxidative stress-related pathologies, including mental illnesses, cancer, obesity, type II diabetes, cardiovascular diseases, and aging [2,4,9-14]. Thus, it has become increasingly evident that circadian clocks play crucial roles in the orchestration of life according to time of day, and most physiological functions are tightly locked to an organism's activity and rest phases to ensure optimal performance.

Like many other physiological processes, fluid intake, urine production, and urine storage display distinct daily and circadian variations as discussed below. Yet, the precise mechanism or mechanisms underlying these variations remain largely unex-
Corresponding author: Sehyung Cho

Department of Physiology, Kyung Hee University School of Medicine,

1 Hoegi-dong, Dongdaemun-gu, Seoul 130-701, Korea

Tel: +82-2-961-0984/ Fax: +82-2-969-6343 / E-mail:sehyung@khu.ac.kr

Submitted: June 10, 2011 / Accepted after revision: June 20, 2011
This is an Open Access article distributed under the terms of the Creative Commons Attribution Non-Commercial License (http://creativecommons.org/licenses/by-nc/3.0/) which permits unrestricted non-commercial use, distribution, and reproduction in any medium, provided the original work is properly cited. 
plored. In this review, we briefly introduce circadian systems in mammals and their physiological significances, keeping urological researchers in mind. Then, we explore the known daily and circadian variations in urinary functions. Finally, we discuss future areas of research in terms of circadian control of urinary functions.

\section{THE CIRCADIAN ORGANIZATION IN MAMMALS}

Circadian rhythms are defined not by the molecular mechanisms underlying them but by well-established experimental criteria. For a process to be defined as a circadian behavior, three conditions should be met [15-17]. First, a rhythm must persist with a period of approximately 24 hours, even in the absence of an environmental cycle. The period length observed under constant environmental conditions constitutes the free-running period of a rhythm. Second, the period should vary only slightly at different ambient temperatures within the organism's physiological range. This criterion underlies the temperature compensation of a rhythm that mainly reflects the ability to maintain similar period lengths despite various factors affecting the velocity of biochemical and metabolic reactions, such as body temperature and nutritional status. Finally, the phasing of peaks and troughs relative to a reference point can be reset by environmental cues to which the rhythm entrains. This phase-resetting property allows organisms to accommodate themselves, for example, to the seasonal variations in environmental illumination. The environmental factors that can reset the phase of a rhythm are known as zeitgebers. Some important zeitgebers in mammals include light-dark cycles, temperature cycles, food availability, physical activity, and social cues [16-20].

Conceptually, three basic elements are needed for the proper operation of circadian systems in whole animals. First of all, a functional oscillator or pacemaker is needed that gives the basic drumbeat and sets the period of a rhythm. The suprachiasmatic nucleus ( $\mathrm{SCN}$ ) is now well defined as the master oscillator in mammals $[21,22]$. Experimental lesions in the SCN lead to an immediate loss of rhythmic behaviors [23], whereas persistence of circadian rhythmicity is observed in hypothalamic "islands" containing the SCN [24]. Moreover, fetal SCN transplants restore circadian rhythmicity in SCN-lesioned animals [25] and even determine the period of locomotor activity rhythms of the host animals [26]. The mammalian SCN can be divided into two parts: ventrolateral vs. dorsomedial. The ventrolateral SCN is composed of sparse spherical neurons with organelle-rich cytoplasm that synthesize vasoactive intestinal peptide, peptide histidine isoleucine, and gastrin-releasing peptide. The dorsomedial part of the SCN contains small elongated neurons with large nuclei and few cell organelles that mainly express vasopressin $[21,22]$.

The second element of a circadian system is the presence of input pathways that can correct the non-24-hour basic periodicity of the central pacemaker to 24 hours and adjust the phase to local time. It is now well established that the SCN can be entrained by light-dependent signals via the retinohypothalamic tract [27-30]. A recent study demonstrated that the RHT, one component of the optic nerve, transmits the environmental light signal to four major fields in the hypothalamus: ventrolateral SCN, perisuprachiasmatic region, ventromedial part of the anterior hypothalamus, and ventral zone of the anterior group of the lateral hypothalamic area [29]. Other input pathways to the SCN include neuropeptide Y input from the intergeniculate leaflet via the geniculohypothalamic tract and serotonergic input from the Raphe nuclei [22,31-33]. Moreover, humoral feedback inputs to the SCN are believed to modulate the SCN clock nonphotically. For example, the SCN is one place that contains the highest concentration of melatonin receptors within the body [22,34]. Thus, the mammalian SCN receives information from the environment as well as from within the body and can adjust the relevant physiological rhythms accordingly.

The final element of a circadian system is the neural/humoral output pathways that transfer the rhythmic messages to effector organs of the overt rhythms. Major neural output pathways from the mammalian SCN include the subparaventricular zone, dorsomedial nucleus and medial preoptic area of the hypothalamus, and paraventricular nucleus of the thalamus [22,33,35-37]. In addition, virtually all hormones are secreted rhythmically depending on the time of day $[20,38]$. Indeed, the SCN is believed to play central roles in the circadian control of neuroendocrine functions [39]. In this way, the neural and humoral outputs derived from the central pacemaker govern the circadian rhythms of physiology and behavior.

\section{GENETIC BASIS OF CIRCADIAN RHYTHMS: THE MOLECULAR OSCILLATOR WITHIN THE CELL}

In 1971, Konopka and Benzer [40] reported the first clock mutants of Drosophila. The affected gene, named as period, was 
subsequently cloned [41]. Likewise, the first clock mutant mouse was reported by Vitaterna et al. [42]. Since then, several core clock genes that govern circadian rhythmicity in mammals have been identified [1-4]. These include circadian locomotor output cycle kaput (Clock), neuronal PAS domain protein 2 (Npas2), brain and muscle arnt-like 1 (Bmal1), mammalian homologues of Drosophila period (Per1 and Per2), and two cryptochromes (Cry1 and Cry2). Within the cell, the positive circadian transcription factor complex CLOCK (or NPAS2)/BMAL1 binds to the E-box sequences and transactivates the transcription of target genes, including pers and crys genes (Fig. 1). PERs and CRYs accumulate in the cytoplasm, translocate into the nucleus with a timed delay, and inhibit their own transcription by interacting with the CLOCK/BMAL1 complex [43]. Although this constitutes the primary feedback loop, there exists a second feedback loop involving the Rev-erba gene [44]. REV-ERBa, also transactivated by CLOCK/BMAL1, acts as a strong repressor of the Bmal1 gene, giving robustness to the molecular oscillator.

The characterization of the tau mutant hamster, which harbors an A178C missense mutation in the casein kinase 1 epsilon (Csnkle) gene, has emphasized the role of posttranslational modifications of circadian clock proteins [45,46]. It has subsequently been shown that $\beta$-TrCP and FBXL3 E3 ligase complexes target PERs and CRYs for degradation [47-50]. More recently, AMPK was shown to phosphorylate CRY1 and destabilize it in response to nutrient signals in the mouse liver [51]. Also notable is the chromatin remodeling and other modifications of circadian clock proteins that alter circadian gene expression and function [52-55].

\section{TISSUE-SPECIFIC FUNCTIONS DRIVEN BY PERIPHERAL CLOCKS}

Since the discovery of the circadian clock genes, one of the most striking findings was that circadian gene expression is not confined to the central oscillator in the SCN: circadian genes are expressed in almost every tissue within the body. Even cultured cells in vitro exhibit a robust oscillation of circadian genes in a self-sustained and cell-autonomous manner [56,57], thus allowing the characterization of the regulation and function of circadian genes in vitro [58-60].

Although almost every cell and tissue expresses circadian genes, cycling transcripts are not the same among the tissues or cells. For example, the SCN and the liver have only small portions of cycling transcripts in common [61]. Almost ubiquitous expression of clock genes and cell- and tissue-specificity in the cycling transcripts lead to the concept of peripheral clocks, which is believed to derive tissue-specific functions according to time of day [62-67]. Thus, the hierarchical organization of the central clock in the SCN and local peripheral oscillators in the peripheral tissues seem to generate the harmony of various physiological rhythms in the mammalian circadian timing system.
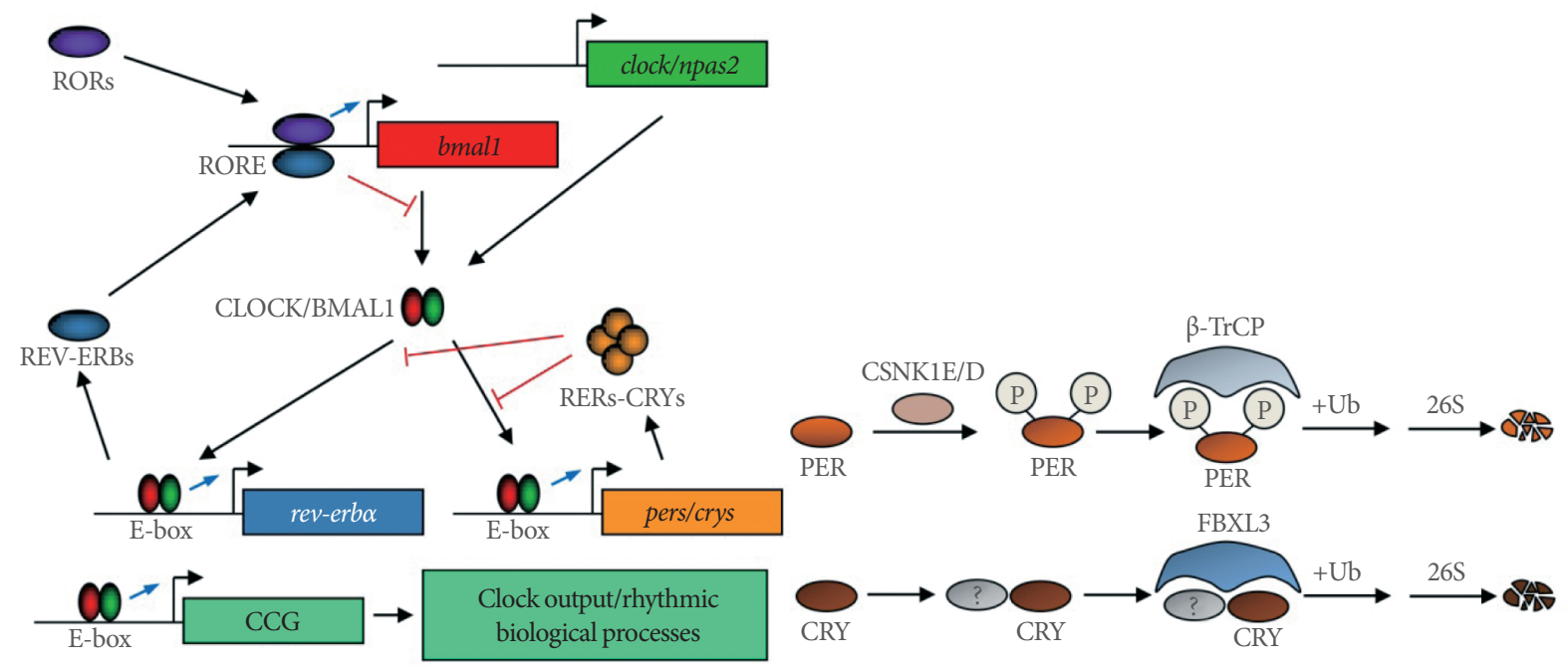

Fig. 1. A current working model of the molecular oscillator in mammals. RORs, RAR-related orphan receptors; RORE, ROR response element; bmal1, brain and muscle arnt-like 1; clock, circadian locomotor output cycle kaput; npas2, neuronal PAS domain protein 2; CCG, clock-controlled gene; CSNK1E/D, casein kinase 1 epsilon/delta; $\beta$-TrCP, $\beta$-transducin repeat-containing protein; FBXL3, F-box and leucine-rich repeat protein 3. 


\section{DAILY/CIRCADIAN RHYTHMS IN URINARY FUNCTION}

With the effective circadian timing system, most physiological functions in mammals are tightly locked to their activity and rest phases to ensure optimal performance. For example, diurnal animals consume most of their food and water during the day, whereas nocturnal animals do so during the night $[20,68]$. Accordingly, water intake, urine production, and urine storage also display distinct daily or circadian variations in diurnal humans and nocturnal rodents (Table 1). As discussed briefly in the previous issue [69], urine production and voiding must predominate during the active phase, whereas increased storage of urine in the bladder and reduced frequency in urination must be ensured to promote better rest and sleep. Consequently, disruption of this homeostatic regulation is predicted to decrease an organism's well-being. For example, nocturia, the complaint that an individual has to wake at night one or more times to void [70], decreases quality of life and negatively affects morbidity and mortality, especially in the elderly [71-74].
Diurnal or circadian variations in urine volume, electrolyte excretion, uroflow, micturition frequency, volume per void, and urine and osmole output rates have been extensively studied [75-82]. For example, water and electrolyte excretion is significantly low during the sleep phase compared with active daytime in healthy control subjects but not in patients with congestive heart failure or cirrhosis of the liver [75]. Moreover, these variations in urinary excretion are observed not only in nychthemeral conditions but also in constant-routine protocols [77], indicating that these rhythms are generated endogenously. Increased urine volume, urine production rate, and frequency during the day along with increased bladder capacity during the night $[79,80]$ substantiates the dominance of voiding during the day with the dominance of urine storage during the night. Interestingly, maximum voided volume in school-aged children with monosymptomatic nocturnal enuresis was shown to be smaller than that in age-matched controls, but the maximum volume obtained after a standard holding exercise was not significantly different from that in the control group, which raises the possibility that there could be a defect in circadian rhythm

Table 1. Known and possible daily and circadian variations in urinary function in humans: day vs. night

\begin{tabular}{|c|c|c|c|}
\hline & Day (activity/awake) & Night (rest/sleep) & Reference No. \\
\hline Dominance & Voiding & Storage & 79,80 \\
\hline Urine production & High & Low & $75-77,80,81$ \\
\hline Voiding frequency & High & Null (very low) & 79,80 \\
\hline $\mathrm{pAVP}(\mathrm{ADH})$ & Low & High & $85-93$ \\
\hline pANP & Low & High & 95,96 \\
\hline PRA/PA (activity) & High & Low & 94,95 \\
\hline PRA/PA (recumbency) & Low & High & 94,95 \\
\hline GFR & High & Low & 83,84 \\
\hline Electrolyte excretion & High & Low & 75,77 \\
\hline $\mathrm{FE}_{\mathrm{Na}} \%$ & High & Low & 84 \\
\hline $\mathrm{U}_{\mathrm{K}} /\left(\mathrm{U}_{\mathrm{Na}+\mathrm{K}}\right) \%$ & High & Low & 84 \\
\hline Urine osmolality & Low & High & 76,84 \\
\hline Detrusor contractility & $\operatorname{High}(?)$ & Low (?) & 82 \\
\hline Functional bladder capacity & Low (?) & High (?) & $79-82$ \\
\hline Sympathetic tone & High (?) & Low (?) & 98 \\
\hline Parasympathetic tone & Low (?) & High (?) & 98 \\
\hline Pressure-sensing in the bladder & $? ?$ & $? ?$ & \\
\hline Activity of PMC & $? ?$ & $? ?$ & \\
\hline Cortical control of micturition & $? ?$ & $? ?$ & \\
\hline
\end{tabular}

pAVP, plasma arginine vasopressin; ADH, antidiuretic hormone; PRA/PA, plasma renin activity or plasma aldosterone; GFR, glomerular filtration rate; $\mathrm{FE}_{\mathrm{Na}} \%$, fractional sodium excretion; $\mathrm{U}_{\mathrm{K}} /\left(\mathrm{U}_{\mathrm{Na}+\mathrm{K}}\right) \%$, fractional distal sodium-potassium exchange; PMC, pontine micturition center. 
for detrusor inhibition $[81,82]$.

One of the well-known circadian rhythms in humans is the rhythm of glomerular and tubular function. Independent of circulating hormones, the glomerular filtration rate decreases by 15 to $30 \%$ overnight $[83,84]$. Nonetheless, many circulating hormones greatly affect urine production and storage. Of these, arginine vasopressin (AVP) displays a distinct diurnal/circadian variation and has been implicated in many urological problems, and its synthetic analog desmopressin has been widely used as a therapeutic agent [85-93]. Importantly, alterations or dampening of diurnal rhythms in the plasma AVP level have been linked to many urological problems including urological aging $[86,87,90,91,93]$, further emphasizing the importance of proper circadian control in hormone secretion. Other urinary function-related hormones that exhibit diurnal or circadian fluctuations include plasma renin, aldosterone, atrial natriuretic peptide, cortisol, and prostaglandins [94-97] (Table 1). Thus, the harmonious secretion of these hormones may contribute to the distinct circadian variation in urinary functions.

Also notable is the daily variation in sympathetic/parasympathetic tone [98], considering the importance of the autonomic nervous system in bladder function. However, increased sympathetic tone during the active phase is quite contradictory to the notion that urine storage must predominate during the rest period. Yet, local bladder control of the autonomic nervous system still remains an intriguing possibility. Finally, the circadian control of blood pressure needs to be considered when examining urinary rhythms, because electrolyte excretion plays crucial roles in the control of blood pressure, and the dysregulation of blood pressure has wide significance for many human pathologies [99-101].

\section{ROLES OF CIRCADIAN CLOCKS IN URINARY FUNCTION?}

Despite the ample evidence supporting clear circadian and diurnal variations in urine production and storage, the mechanism or mechanisms underlying this variation are largely unknown. Do circadian clocks, especially the local clocks in the kidney and bladder if they exist, have any significant roles? Two recent studies support this possibility. Zuber et al. [102] demonstrated a local renal clock that may derive time-of-day-dependent renal functions. In their study, clock $^{-1-}$ mice exhibited a complex phenotype with partial diabetes insipidus, dysregulation of sodium excretion rhythms, and a significant decrease in blood pressure [102]. A urodynamic study by Herrera and Meredith [103] demonstrated day/night differences in bladder capacity and micturition frequency in rats, raising the possibility that the bladder itself can be a direct target for circadian regulation. Although more research is needed to clarify the role of clock genes in urinary functions, recent observations obtained in our own research group support this (Fig. 2). We investigated the daily and circadian patterns of urine volume in wild-type (WT) and per1 ${ }^{-1}$ per2-- (PDK) mice under the light-dark (LD) and constant darkness (dark-dark cycle, DD) conditions. Although both WT and PDK mice exhibited clear daily variations of urine volume in the LD condition, PDK mice lost this rhythmicity just 2 days after being released to DD. Moreover, urinary volume in PDK mice was significantly higher than in WT mice.

\section{RESEARCH DIRECTIONS}

As discussed so far, the circadian control of voiding function is undoubtedly an intriguing possibility and needs the immediate attention of researchers in the field. With several clock mutant animals available, novel approaches are needed to delineate whether urinary functions are under the direct control of the mammalian time-keeping system. First of all, the possible existence of a local bladder clock and its functional significance needs to be addressed. Clock genes oscillating and cycling transcriptome/proteome profiling in the detrusor, urothelium, and sphincter remain unexplored. A second path of research is whether there exist circadian variations in the neural control of the bladder. Because various anatomical locations including the bladder itself, spinal cord, pontine micturition center, and cortical sites contribute to the neural control of bladder function [104-106], possible circadian control in these sites needs to be addressed. Other paths of research include consequences of circadian rhythm disruption in terms of urinary functions and vice versa. Indeed, some research has shown that nocturia and polyuria disrupt sleep architecture and may predict obstructive sleep apnea, whereas acute sleep deprivation results in excess diuresis and natriuresis [107-109]. Also interesting will be the causal relationships between circadian and urological aging [71-74, 110-112].

In modern society, more and more workers are engaged in various shift work and trans-meridian travel, thus repetitively disturbing their circadian rhythms. Moreover, urological problems, such as nocturia, polyuria, and nocturnal enuresis, are the major complaints of the elderly in this aged society. Therefore, 

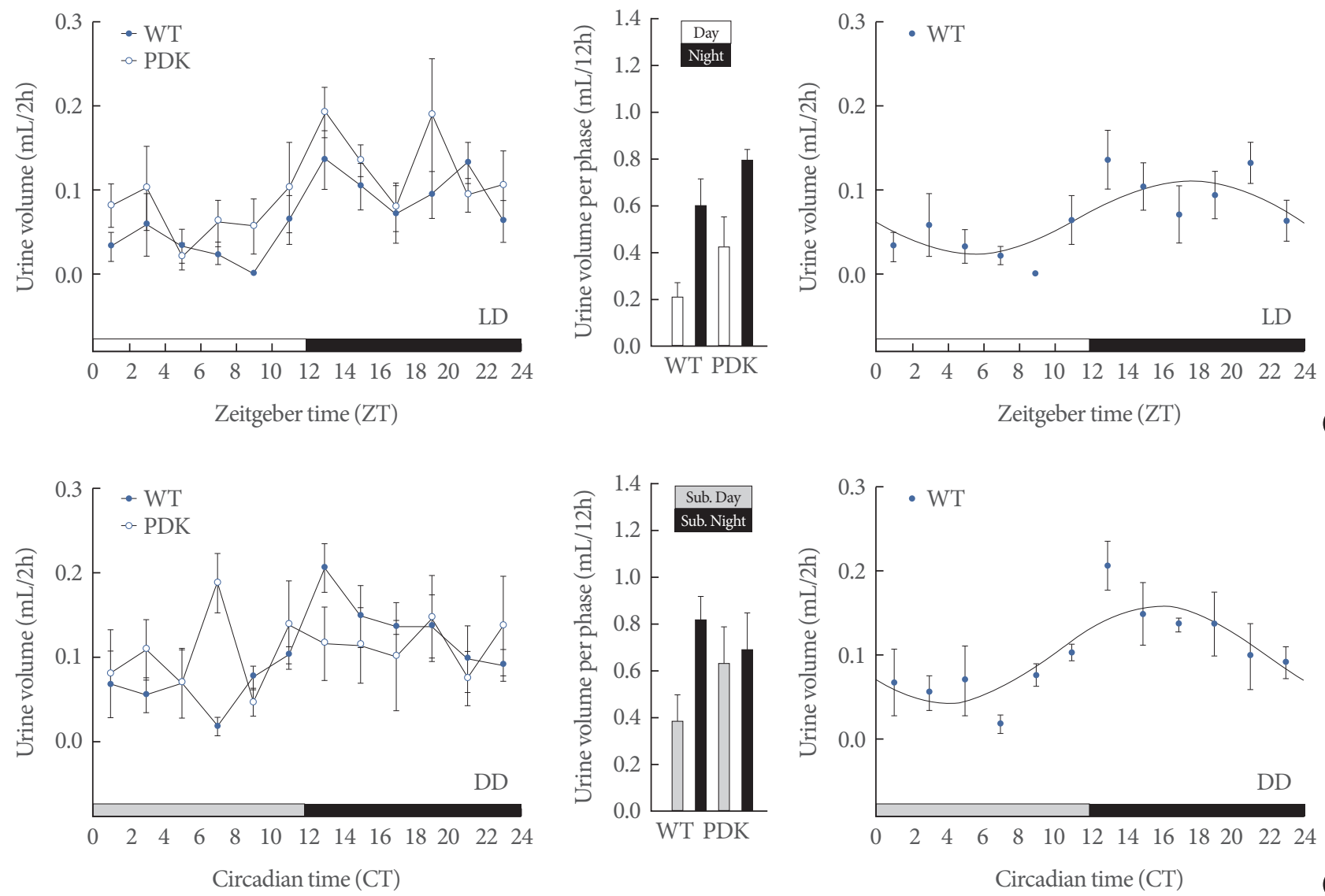

Fig. 2. Functional clock-dependent rhythms in urinary volume in mice. C57BL/6J male wild-type (WT) and per $1^{-1}$ per2 ${ }^{-1-}$ (PDK) mice were first entrained to a 12 hours:12 hours light-dark photoperiodic cycle in metabolic cages for 2 weeks. Once the animals were fully entrained, urine was collected and volumes were measured every 2 hours over a period of 24 hours (A). Mice were then released to constant darkness (dark-dark cycle, DD). Starting on the second day after lights off, urine was collected and volumes were measured over a circadian cycle (B). Urine volumes measured every 2 hours (left), urine volumes calculated per each phase (middle), and cosinor analysis of urine volumes in WT mice (right) are shown here.

the possible circadian control of urinary function is a sure road that needs to be trodden by researchers in the field.

\section{CONFLICT OF INTEREST}

No potential conflict of interest relevant to this article was reported.

\section{ACKNOWLEDGEMENTS}

This research was supported by Basic Science Research Program through the National Research Foundation of Korea (NRF) funded by the Ministry of Education, Science and Technology (R11-2008-036-03004-0).

\section{REFERENCES}

1. Dunlap JC. Molecular bases for circadian clocks. Cell 1999;96: 271-90.

2. Levi F, Schibler U. Circadian rhythms: mechanisms and therapeutic implications. Annu Rev Pharmacol Toxicol 2007;47:593-628.

3. Hastings MH, Maywood ES, O'Neill JS. Cellular circadian pacemaking and the role of cytosolic rhythms. Curr Biol 2008;18: R805-15.

4. Takahashi JS, Hong HK, Ko CH, McDearmon EL. The genetics of mammalian circadian order and disorder: implications for physiology and disease. Nat Rev Genet 2008;9:764-75.

5. Gehring W, Rosbash M. The coevolution of blue-light photoreception and circadian rhythms. J Mol Evol 2003;57 Suppl 1:S286-9. 
6. Cho S. Oxidative stress and circadian rhythm. BMB News 2008; 28:12-9.

7. Chen Z, McKnight SL. A conserved DNA damage response pathway responsible for coupling the cell division cycle to the circadian and metabolic cycles. Cell Cycle 2007;6:2906-12.

8. Foster RG, Kreitzman L. Rhythms of Life. New Haven: Yale University Press; 2008.

9. Ko CH, Takahashi JS. Molecular components of the mammalian circadian clock. Hum Mol Genet 2006;15 Spec No 2:R271-7.

10. Haus E, Smolensky M. Biological clocks and shift work: circadian dysregulation and potential long-term effects. Cancer Causes Control 2006;17:489-500.

11. Scheer FA, Hilton MF, Mantzoros CS, Shea SA. Adverse metabolic and cardiovascular consequences of circadian misalignment. Proc Natl Acad Sci U S A 2009;106:4453-8.

12. Turek FW, Joshu C, Kohsaka A, Lin E, Ivanova G, McDearmon E, et al. Obesity and metabolic syndrome in circadian Clock mutant mice. Science 2005;308:1043-5.

13. Kondratov RV, Kondratova AA, Gorbacheva VY, Vykhovanets OV, Antoch MP. Early aging and age-related pathologies in mice deficient in BMAL1, the core componentof the circadian clock. Genes Dev 2006;20:1868-73.

14. Martino TA, Oudit GY, Herzenberg AM, Tata N, Koletar MM, Kabir GM, et al. Circadian rhythm disorganization produces profound cardiovascular and renal disease in hamsters. Am J Physiol Regul Integr Comp Physiol 2008;294:R1675-83.

15. Pittendrigh CS. Circadian rhythms and the circadian organization of living systems. Cold Spring Harb Symp Quant Biol 1960; 25:159-84.

16. Johnson CH, Elliott J, Foster R, Honma KI, Kronauer R. Fundamental properties of circadian rhythms. In: Dunlap JC, Loros JJ, DeCoursey PJ, editors. Chronobiology: biological timekeeping. Sunderland: Sinauer Associates; 2004. p.67-105.

17. Refinetti R. Circadian Physiology, 2nd ed. Boca Raton: Taylor \& Francis; 2006.

18. Hirota T, Fukada Y. Resetting mechanism of central and peripheral circadian clocks in mammals. Zoolog Sci 2004;21:359-68.

19. Mistlberger RE, Skene DJ. Social influences on mammalian circadian rhythms: animal and human studies. Biol Rev Camb Philos Soc 2004;79:533-56.

20. Challet E. Minireview: entrainment of the suprachiasmatic clockwork in diurnal and nocturnal mammals. Endocrinology 2007; 148:5648-55.

21. van Esseveldt KE, Lehman MN, Boer GJ. The suprachiasmatic nucleus and the circadian time-keeping system revisited. Brain
Res Brain Res Rev 2000;33:34-77.

22. DeCoursey PJ. Functional organization of circadian system in muticellular animals. In: Dunlap JC, Loros JJ, DeCoursey PJ, editors. Chronobiology: biological timekeeping. Sunderland: Sinauer Associates; 2004. p.145-78.

23. Stephan FK, Zucker I. Circadian rhythms in drinking behavior and locomotor activity of rats are eliminated by hypothalamic lesions. Proc Natl Acad Sci U S A 1972;69:1583-6.

24. Inouye ST, Kawamura H. Persistence of circadian rhythmicity in a mammalian hypothalamic "island" containing the suprachiasmatic nucleus. Proc Natl Acad Sci U S A 1979;76:5962-6.

25. Lehman MN, Silver R, Gladstone WR, Kahn RM, Gibson M, Bittman EL. Circadian rhythmicity restored by neural transplant. Immunocytochemical characterization of the graft and its integration with the host brain. J Neurosci 1987;7:1626-38.

26. Ralph MR, Foster RG, Davis FC, Menaker M. Transplanted suprachiasmatic nucleus determines circadian period. Science 1990; 247:975-8.

27. Berson DM, Dunn FA, Takao M. Phototransduction by retinal ganglion cells that set the circadian clock. Science 2002;295:1070-3.

28. Warren EJ, Allen CN, Brown RL, Robinson DW. Intrinsic light responses of retinal ganglion cells projecting to the circadian system. Eur J Neurosci 2003;17:1727-35.

29. Canteras NS, Ribeiro-Barbosa ER, Goto M, Cipolla-Neto J, Swanson LW. The retinohypothalamic tract: comparison of axonal projection patterns from four major targets. Brain Res Rev 2011;65: 150-83.

30. Moldavan MG, Allen CN. Retinohypothalamic tract synapses in the rat suprachiasmatic nucleus demonstrate short-term synaptic plasticity. J Neurophysiol 2010;103:2390-9.

31. Moore RY, Leak RK. Suprachiasmatic nucleus. In: Takahashi JS, Turek FW, Moore RY, editors. Circadian clocks. New York: Kluwer Academic; 2008. p. 141-71. (Handbook of Behavioral Neurobiology; vol. 12).

32. Hay-Schmidt A, Vrang N, Larsen PJ, Mikkelsen JD. Projections from the raphe nuclei to the suprachiasmatic nucleus of the rat. J Chem Neuroanat 2003;25:293-310.

33. Abrahamson EE, Moore RY. Suprachiasmatic nucleus in the mouse: retinal innervation, intrinsic organization and efferent projections. Brain Res 2001;916:172-91.

34. Arendt J. Melatonin and the mammalian pineal gland. New York: Chapman Hall; 1995.

35. Deurveilher S, Burns J, Semba K. Indirect projections from the suprachiasmatic nucleus to the ventrolateral preoptic nucleus: a dual tract-tracing study in rat. Eur J Neurosci 2002;16:1195-213. 
36. Deurveilher S, Semba K. Indirect projections from the suprachiasmatic nucleus to major arousal-promoting cell groups in rat: implications for the circadian control of behavioural state. Neuroscience 2005; 130:165-83.

37. Schwartz MD, Urbanski HF, Nunez AA, Smale L. Projections of the suprachiasmatic nucleus and ventral subparaventricular zone in the Nile grass rat (Arvicanthis niloticus). Brain Res 2011;1367: 146-61.

38. Hastings MH, Maywood ES, Reddy AB. Two decades of circadian time. J Neuroendocrinol 2008;20:812-9.

39. Kalsbeek A, Perreau-Lenz S, Buijs RM. A network of (autonomic) clock outputs. Chronobiol Int 2006;23:201-15.

40. Konopka RJ, Benzer S. Clock mutants of Drosophila melanogaster. Proc Natl Acad Sci U S A 1971;68:2112-6.

41. Reddy P, Zehring WA, Wheeler DA, Pirrotta V, Hadfield C, Hall JC, et al. Molecular analysis of the period locus in Drosophila melanogaster and identification of a transcript involved in biological rhythms. Cell 1984;38:701-10.

42. Vitaterna MH, King DP, Chang AM, Kornhauser JM, Lowrey PL, McDonald JD, et al. Mutagenesis and mapping of a mouse gene, Clock, essential for circadian behavior. Science 1994;264:719-25.

43. Lee C, Etchegaray JP, Cagampang FR, Loudon AS, Reppert SM. Posttranslational mechanisms regulate the mammalian circadian clock. Cell 2001;107:855-67.

44. Preitner N, Damiola F, Lopez-Molina L, Zakany J, Duboule D, Albrecht $U$, et al. The orphan nuclear receptor REV-ERBalpha controls circadian transcription within the positive limb of the mammalian circadian oscillator. Cell 2002;110:251-60.

45. Lowrey PL, Shimomura K, Antoch MP, Yamazaki S, Zemenides $\mathrm{PD}$, Ralph MR, et al. Positional syntenic cloning and functional characterization of the mammalian circadian mutation tau. Science 2000;288:483-92.

46. Meng QJ, Logunova L, Maywood ES, Gallego M, Lebiecki J, Brown TM, et al. Setting clock speed in mammals: the CK1 epsilon tau mutation in mice accelerates circadian pacemakers by selectively destabilizing PERIOD proteins. Neuron 2008;58:78-88.

47. Shirogane T, Jin J, Ang XL, Harper JW. SCFbeta-TRCP controls clock-dependent transcription via casein kinase 1-dependent degradation of the mammalian period-1 (Per1) protein. J Biol Chem 2005;280:26863-72.

48. Busino L, Bassermann F, Maiolica A, Lee C, Nolan PM, Godinho SI, et al. SCFFbxl3 controls the oscillation of the circadian clock by directing the degradation of cryptochrome proteins. Science 2007;316:900-4.

49. Siepka SM, Yoo SH, Park J, Song W, Kumar V, Hu Y, et al. Circa- dian mutant overtime reveals F-box protein FBXL3 regulation of cryptochrome and period gene expression. Cell 2007;129:1011-23.

50. Godinho SI, Maywood ES, Shaw L, Tucci V, Barnard AR, Busino L, et al. The after-hours mutant reveals a role for Fbxl3 in determining mammalian circadian period. Science 2007;316:897-900.

51. Lamia KA, Sachdeva UM, DiTacchio L, Williams EC, Alvarez JG, Egan DF, et al. AMPK regulates the circadian clock by cryptochrome phosphorylation and degradation. Science 2009;326:43740.

52. Hirayama J, Sahar S, Grimaldi B, Tamaru T, Takamatsu K, Nakahata Y, et al. CLOCK-mediated acetylation of BMAL1 controls circadian function. Nature 2007;450:1086-90.

53. Nakahata Y, Kaluzova M, Grimaldi B, Sahar S, Hirayama J, Chen $\mathrm{D}$, et al. The NAD+-dependent deacetylase SIRT1 modulates CLOCK-mediated chromatin remodeling and circadian control. Cell 2008;134:329-40.

54. Asher G, Gatfield D, Stratmann M, Reinke H, Dibner C, Kreppel F, et al. SIRT1 regulates circadian clock gene expression through PER2 deacetylation. Cell 2008;134:317-28.

55. Asher G, Reinke H, Altmeyer M, Gutierrez-Arcelus M, Hottiger MO, Schibler U. Poly (ADP-ribose) polymerase 1 participates in the phase entrainment of circadian clocks to feeding. Cell 2010; 142:943-53.

56. Balsalobre A, Damiola F, Schibler U. A serum shock induces circadian gene expression in mammalian tissue culture cells. Cell 1998;93:929-37.

57. Nagoshi E, Saini C, Bauer C, Laroche T, Naef F, Schibler U. Circadian gene expression in individual fibroblasts: cell-autonomous and self-sustained oscillators pass time to daughter cells. Cell 2004;119:693-705.

58. Cho S, Yujnovsky I, Doi M, Sassone-Corsi P. Transplantation of mouse embryo fibroblasts: an approach to study the physiological pathways linking the suprachiasmatic nucleus and peripheral clocks. Methods Enzymol 2005;393:469-78.

59. Doi M, Cho S, Yujnovsky I, Hirayama J, Cermakian N, Cato AC, et al. Light-inducible and clock-controlled expression of MAP kinase phosphatase 1 in mouse central pacemaker neurons. J Biol Rhythms 2007;22:127-39.

60. Shim HS, Kim H, Lee J, Son GH, Cho S, Oh TH, et al. Rapid activation of CLOCK by $\mathrm{Ca} 2+$-dependent protein kinase $\mathrm{C}$ mediates resetting of the mammalian circadian clock. EMBO Rep 2007;8: 366-71.

61. Panda S, Antoch MP, Miller BH, Su AI, Schook AB, Straume M, et al. Coordinated transcription of key pathways in the mouse by the circadian clock. Cell 2002;109:307-20. 
62. Bray MS, Young ME. The role of cell-specific circadian clocks in metabolism and disease. Obes Rev 2009;10 Suppl 2:6-13.

63. Cermakian N, Boivin DB. The regulation of central and peripheral circadian clocks in humans. Obes Rev 2009;10 Suppl 2:25-36.

64. Escobar C, Cailotto C, Angeles-Castellanos M, Delgado RS, Buijs RM. Peripheral oscillators: the driving force for food-anticipatory activity. Eur J Neurosci 2009;30:1665-75.

65. Dibner C, Schibler U, Albrecht U. The mammalian circadian timing system: organization and coordination of central and peripheral clocks. Annu Rev Physiol 2010;72:517-49.

66. Sellix MT, Menaker M. Circadian clocks in the ovary. Trends Endocrinol Metab 2010;21:628-36.

67. Chung S, Son GH, Kim K. Adrenal peripheral oscillator in generating the circadian glucocorticoid rhythm. Ann N Y Acad Sci 2011;1220:71-81.

68. Kafka MS, Benedito MA, Steele LK, Gibson MJ, Zerbe RL, Jacobowitz DM, et al. Relationships between behavioral rhythms, plasma corticosterone and hypothalamic circadian rhythms. Chronobiol Int 1986;3:117-22.

69. Cho S, Han DH, Kim DH. Circadian rhythms in voiding function and dysfunction. Int Neurourol J 2011;15:2-3.

70. Abrams P, Cardozo L, Fall M, Griffiths D, Rosier P, Ulmsten U, et al. The standardisation of terminology in lower urinary tract function: report from the standardisation sub-committee of the International Continence Society. Urology 2003;61:37-49.

71. Chasens ER, Umlauf MG. Nocturia: a problem that disrupts sleep and predicts obstructive sleep apnea. Geriatr Nurs 2003;24:76-81, 105.

72. Ali A, Snape J. Nocturia in older people: a review of causes, consequences, assessment and management. Int J Clin Pract 2004; 58:366-73.

73. Nørgaard JP, Hashim H, Malmberg L, Robinson D. Antidiuresis therapy: mechanism of action and clinical implications. Neurourol Urodyn 2007;26:1008-13.

74. Kujubu DA, Aboseif SR. An overview of nocturia and the syndrome of nocturnal polyuria in the elderly. Nat Clin Pract Nephrol 2008:4:426-35.

75. Goldman R. Studies in diurnal variation of water and electrolyte excretion; nocturnal diuresis of water and sodium in congestive cardiac failure and cirrhosis of the liver. J Clin Invest 1951;30: 1191-9.

76. Mills JN. Diurnal rhythm in urine flow. J Physiol 1951;113:528-36.

77. Minors DS, Waterhouse JM. Circadian rhythms of urinary excretion: the relationship between the amount excreted and the circadian changes. J Physiol 1982;327:39-51.
78. Witjes WP, Wijkstra H, Debruyne FM, de la Rosette JJ. Quantitative assessment of uroflow: is there a circadian rhythm? Urology 1997;50:221-8.

79. van Haarst EP, Heldeweg EA, Newling DW, Schlatmann TJ. The 24-h frequency-volume chart in adults reporting no voiding complaints: defining reference values and analysing variables. BJU Int 2004;93:1257-61.

80. Parsons M, Tissot W, Cardozo L, Diokno A, Amundsen CL, Coats AC, et al. Normative bladder diary measurements: night versus day. Neurourol Urodyn 2007;26:465-73.

81. Van Hoeck K, Bael A, Lax H, Hirche H, van Gool JD. Circadian variation of voided volume in normal school-age children. Eur J Pediatr 2007;166:579-84.

82. Van Hoeck K, Bael A, Lax H, Hirche H, Van Dessel E, Van Renthergem $\mathrm{D}$, et al. Urine output rate and maximum volume voided in school-age children with and without nocturnal enuresis. J Pediatr 2007;151:575-80.

83. Kamperis K, Hansen MN, Hagstroem S, Hvistendahl G, Djurhuus JC, Rittig S. The circadian rhythm of urine production, and urinary vasopressin and prostaglandin E2 excretion in healthy children. J Urol 2004;171(6 Pt 2):2571-5.

84. De Guchtenaere A, Vande Walle C, Van Sintjan P, Raes A, Donckerwolcke R, Van Laecke E, et al. Nocturnal polyuria is related to absent circadian rhythm of glomerular filtration rate. J Urol 2007; 178:2626-9.

85. Landgraf R, Häcker R, Buhl H. Plasma vasopressin and oxytocin in response to exercise and during a day-night cycle in man. Endokrinologie 1982;79:281-91.

86. Rittig S, Knudsen UB, Nørgaard JP, Pedersen EB, Djurhuus JC. Abnormal diurnal rhythm of plasma vasopressin and urinary output in patients with enuresis. Am J Physiol 1989;256(4 Pt 2): F664-71.

87. Asplund R, Aberg H. Diurnal variation in the levels of antidiuretic hormone in the elderly. J Intern Med 1991;229:131-4.

88. Kuo HC. Efficacy of desmopressin in treatment of refractory nocturia in patients older than 65 years. Urology 2002;59:485-9.

89. Sakakibara R, Matsuda S, Uchiyama T, Yoshiyama M, Yamanishi T, Hattori T. The effect of intranasal desmopressin on nocturnal waking in urination in multiple system atrophy patients with nocturnal polyuria. Clin Auton Res 2003;13:106-8.

90. Moon DG, Jin MH, Lee JG, Kim JJ, Kim MG, Cha DR. Antidiuretic hormone in elderly male patients with severe nocturia: a circadian study. BJU Int 2004;94:571-5.

91. Hirayama A, Fujimoto K, Akiyama T, Hirao Y. Decrease in nocturnal urinary levels of arginine vasopressin in patients with noc- 
turnal polyuria. Urology 2006;68:19-23.

92. De Guchtenaere A, Vande Walle C, Van Sintjan P, Donckerwolcke R, Raes A, Dehoorne J, et al. Desmopressin resistant nocturnal polyuria may benefit from furosemide therapy administered in the morning. J Urol 2007;178:2635-9.

93. Rittig S, Schaumburg HL, Siggaard C, Schmidt F, Djurhuus JC. The circadian defect in plasma vasopressin and urine output is related to desmopressin response and enuresis status in children with nocturnal enuresis. J Urol 2008;179:2389-95.

94. Cugini P, Murano G, Lucia P, Letizia C, Scavo D, Halberg F, et al. Circadian rhythms of plasma renin activity and aldosterone: changes related to age, sex, recumbency and sodium restriction. Chronobiologic specification for reference values. Chronobiol Int 1985;2:267-76.

95. Portaluppi F, Bagni B, degli Uberti E, Montanari L, Cavallini R, Trasforini G, et al. Circadian rhythms of atrial natriuretic peptide, renin, aldosterone, cortisol, blood pressure and heart rate in normal and hypertensive subjects. J Hypertens 1990;8:85-95.

96. Portaluppi F, Vergnani L, degli Uberti EC. Atrial natriuretic peptide and circadian blood pressure regulation: clues from a chronobiological approach. Chronobiol Int 1993;10:176-89.

97. Kuznetsova AA, Shakhmatova EI, Prutskova NP, Natochin YV. Possible role of prostaglandins in pathogenesis of nocturnal enuresis in children. Scand J Urol Nephrol 2000;34:27-31.

98. Lakatua DJ, Haus E, Halberg F, Halberg E, Wendt HW, SackettLundeen LL, et al. Circadian characteristics of urinary epinephrine and norepinephrine from healthy young women in Japan and U.S.A. Chronobiol Int 1986;3:189-95.

99. Graugaard-Jensen C, Rittig S, Djurhuus JC. Nocturia and circadian blood pressure profile in healthy elderly male volunteers. J Urol 2006;176:1034-9.

100. White WB. Importance of blood pressure control over a 24-hour period. J Manag Care Pharm 2007;13(8 Suppl B):34-9.

101. Bankir L, Bochud M, Maillard M, Bovet P, Gabriel A, Burnier M. Nighttime blood pressure and nocturnal dipping are associated with daytime urinary sodium excretion in African subjects. Hy- pertension 2008;51:891-8.

102. Zuber AM, Centeno G, Pradervand S, Nikolaeva S, Maquelin L, Cardinaux L, et al. Molecular clock is involved in predictive circadian adjustment of renal function. Proc Natl Acad Sci U S A 2009; 106:16523-8.

103. Herrera GM, Meredith AL. Diurnal variation in urodynamics of rat. PLoS One 2010;5:e12298.

104. Abrams P, Andersson KE. Muscarinic receptor antagonists for overactive bladder. BJU Int 2007;100:987-1006.

105. Ford AP, Gever JR, Nunn PA, Zhong Y, Cefalu JS, Dillon MP, et al. Purinoceptors as therapeutic targets for lower urinary tract dysfunction. Br J Pharmacol 2006;147 Suppl 2:S132-43.

106. Kim SE, Ko IG, Kim BK, Sung YH, Shin MS, Cho S, et al. Transplantation of human adipose-derived stem cells into the urethra ameliorates stress urinary incontinence and blunts the induction of c-Fos immunoreactivities in brain areas related to micturition in female rats. Anim Cells Syst 2010;14:237-44.

107. Kaynak H, Kaynak D, Oztura I. Does frequency of nocturnal urination reflect the severity of sleep-disordered breathing? J Sleep Res 2004;13:173-6.

108. Umlauf MG, Chasens ER, Greevy RA, Arnold J, Burgio KL, Pillion DJ. Obstructive sleep apnea, nocturia and polyuria in older adults. Sleep 2004;27:139-44.

109. Kamperis K, Hagstroem S, Radvanska E, Rittig S, Djurhuus JC. Excess diuresis and natriuresis during acute sleep deprivation in healthy adults. Am J Physiol Renal Physiol 2010;299:F404-11.

110. Touitou Y, Haus E. Alterations with aging of the endocrine and neuroendocrine circadian system in humans. Chronobiol Int 2000;17:369-90.

111. Ku JH, Lim DJ, Byun SS, Paick JS, Oh SJ. Nocturia in patients with lower urinary tract symptoms: association with diurnal voiding patterns. BJU Int 2004;93:1005-8.

112. Sugaya K, Nishijima S, Oda M, Owan T, Miyazato M, Ogawa Y. Biochemical and body composition analysis of nocturia in the elderly. Neurourol Urodyn 2008;27:205-11. 